\title{
Multiple Intelligence Measurement through Performance Tests in Students of 1st High School, Tana Toraja
}

\author{
Hengki Wijaya $^{{ }^{*}}$, Indra O S Toding ${ }^{2}$, Harmelia Tulak ${ }^{3}$, Umrati $^{4}$, Sahrul Syawal ${ }^{5}$ \\ \{"hengkiwijaya@sttjaffray.ac.id\} \\ 1,2Sekolah Tinggi Filsafat Jaffray Makassar, Indonesia \\ ${ }^{3}$ Indonesian Christian University of Toraja, Indonesia \\ ${ }^{4}$ Institut Agama Islam As'adiyah Sengkang, Indonesia \\ ${ }^{5}$ University of East Indonesia, Indonesia
}

\begin{abstract}
The theory of multiple-intelligences initiated by Howard Garner because of dissatisfaction with the education system, which introduced the intelligence quotient test system. The multiple-intelligences philosophy has changed the face of education today because it eliminates the distinction provided by schools to students. The multiple intelligences theory emphasizes that each is different and cannot be forced to be equal. This paper aims to discuss multiple-intelligences on student performance tests in 1st High School Tana Toraja. The author provides performance tests and questionnaire instruments to respondents. The results of the performance test and questionnaire instruments which had completed the performance tests and questionnaire instruments. The results showed that the students of 1st High School Tana Toraja were not optimal in using their intelligence to develop their potential. The reason is that students do not understand clearly the type of multiple-intelligence. Students are not interested in improving their type of multiple-intelligence and are more interested in developing other intelligence potentials.
\end{abstract}

Keywords : Intelligence, Performance, Studentds

\section{Introduction}

A student who has logic and linguistics has a greater opportunity to continue to a better level of education. Students who have logical (mathematical) and linguistic (language) intelligence will certainly be able to develop their potential well because all subjects need reasoning and abstract thinking skills and the ability to communicate well.

Gardner understands that logic and interpersonal skills are also important. In modern schools language is still important, logic is more important, but interpersonal is not very valued. He explained that intrapersonal intelligence is also important where you really need to know your own skills, especially if you live in a pluralistic society [1].

In reality in the world of education, there are many students who lack logic and linguistics. If the education system in Indonesia continues to use the traditional understanding 
of intelligence, where students who are considered intelligent are students who have logical intelligence supported by the value of learning outcomes that are above average and have a high IQ. So in the education system discrimination will occur because the education system will only respect and try to develop the intelligence potential of students who have logical and linguistic intelligence, but ignore and try to impose other students who are lacking in these abilities to have the same learning achievement. Definition of intelligence is the ability to overcome problems and create products that are valued more than one or more of various cultures [2]. Thus intelligence cannot be limited only by cognitive (intellectual) assessment, but also by looking at creativity, and art and interpersonal, and intrapersonal abilities. Teachers need to pay attention and develop the potential of their students to improve their intelligence according to their talents and gifts.

All students should be able to develop their own potential but in reality in the world of education in Indonesia today, especially at the level of High School. Gardner revealed that not all students can develop their own potential because of the lack of understanding of students about the intelligence possessed and how to develop that intelligence so that the potential that exists in each student can be achieved [3]. Self-factor becomes a determinant for students to develop their own potential in accordance with the outstanding intelligence possessed. In addition, the cause of students not being able to develop their own potential in accordance with the type of prominent intelligence they have is that the school is not able to foster all existing students with the type of intelligence they have. Gardner also sees schools tend to pay more attention and respect to students who excel in logic (mathematics) and language skills but pay less attention to students who have other intelligence [3]. People with higher personal intelligence must know themselves better than those who have lower personal intelligence, and those who are higher in intellectual intelligence personally must be able to know what kind of experience is more meaningful to them [4]. Thus each student knows his potential because they have their own intrapersonal intelligence. This study aims to determine the results of performance tests, and explain the relationship of multiple intelligence theories to the development of students' self potential. This paper will present the results of research on multiple intelligences, and the potential of students through literature review. Then explain the results of the performance test, and the results of the questionnaire through a descriptive literature review.

\section{Literature Review}

n 2005 for various considerations from the research conducted, Walter MCKenzie in his book entitled Multiple Intelligences and Instructional Technology has included existentialspiritual intelligence as one type of intelligence in the theory of multiple intelligences [5]. The types of intelligence are: 1) verbal-linguistic intelligence; 2) logical-mathematical intelligence; 3) visual-spatial intelligence; 4) musical intelligence; 5) physical-kinesthetic intelligence; 6) interpersonal intelligence; 7) intrapersonal intelligence; 8) naturalistic intelligence; 9) existential-spiritual intelligence. The finding that some non-cognitive tests are part of the research shows that Gardner may be right in claiming that Kinesthetic-Body abilities are very different from various cognitive abilities. Given the important contribution of non-cognitive abilities and cognitive abilities to performance in the Kinesthetic-Kinesthetic, Musical, and Intrapersonal domains, the label "talent" is more appropriate than the term "intelligence" [6]. In learning English, the results showed that there were significant differences between the 
increase in General English courses between the experimental and control groups. In other words, students who teach based on multiple intelligence theories exceed students who are traditionally instructed both in general and in each sub-English learning skills (vocabulary, reading comprehension, and structure). The results also showed that students' attitudes towards learning English in the experimental group increased significantly [7]. Thus using multiple intelligences has more impact than just using one or two intelligences.

Abdulkarim and Al Jadiry's research shows that there are statistically significant differences in scientific thinking skills $\alpha=0.05$ associated with the division of cooperative learning groups based on several theories of intelligence (logical mathematical intelligence, spatial intelligence) and prior achievement (low achievement, high achievement) and there are statistically significant ones. Differences in the development of scientific thinking skills, interactions between the divisions of cooperative learning groups based on the theory of multiple intelligences and previous achievements. This study recommends educators to do so using the theory of multiple intelligences in cooperative learning as a new approach to dividing groups [8]. Suplig's research results on social intelligence can be described as interpersonal intelligence, namely intelligence in socializing with friends. Research on game addiction has influenced social intelligence because they replaced friendship with the virtual world, namely playing games [9]. According to Safarai, interpersonal intelligence is also said to be a social intelligence, a person's abilities and skills in creating social relations so that both parties are in a favorable situation [10]. Interpersonal intelligence is the ability to understand and cooperate with others [11]. The results of Taase's study of the application of the theory of intelligence in textbooks were found to show that linguistic and spatial intelligence were the most common. Whereas mathematical logical intelligence, interpersonal and intrapersonal intelligence is found in a much lower ratio. But textbooks that have not been written using the theory of multiple intelligences [12]. Cerruti argues that when the field of neuroscience develops, multiple intelligences may be a very useful foundation for building appropriate scientific theories about the process of neurocognitive learning - theories that are at the level of description that the teacher thinks are quite intuitive. For researchers, a functional theory will help organize experimental research in the mind, brain, and education, three disciplines that examine cognition and behavior at various levels of description. For teachers, the specification of the functional nature of intelligence will help guide instructional decisions about how a child's mind learns [13]. Multiple intelligence theory helps teachers and students to know their intelligence and develop it along with other sciences in learning and learning. Han and Wang's research examined media and network applications in the development of multiple intelligences. The conclusion is that the application of multimedia technology and networks can maximize multiple intelligences and increase them reciprocally. It is important that teaching English in college and multiple intelligences must support and interact with each of them for the best results [14]. The benefits for students are being able to analyze, solve problems, the ability to apply theory, the ability to control themselves, and explore their potential in learning English.

\section{Research Methodology}

\subsection{Participant}

State High School 1 Tana Toraja has two types of specialization options, namely Science and Social Sciences. For each grade level, there are 7 specialization classes in Science and 3 
classes in Social Sciences. The population in the study conducted by the authors were all class $\mathrm{X}$ specialization in science and social studies, while the research samples were class X IPA 1 and X IPS 1 . The number of students in class X IPA 1 was 36 people and the number of students in class X IPS 1 was 33 people. In carrying out research at the Tana Toraja State High School 1, the author gave a performance test to all students from X 1 Science and X IPS 1 totaling 69 people.

\subsection{Data collection technique}

Data collection techniques used in this study were performance tests, observation of the research team, and interviews with teachers and students regarding emotional intelligence. According to the Personal and Lesatari, the performance test is a systematic method that can be used to evaluate learning outcomes that cannot be measured only through objective tests and essay tests. Performance tests can be used to measure students' actual or actual performance which is inadequate if measured only by using an objective test. Skills in writing papers or essays are one example of skills that are difficult if measured only by using an instrument in the form of an objective test. Instruments that are suitable for use to measure the ability to apply the principles in carrying out the process or creating a paper or essay are performance tests [15]. In the performance test given to determine the type of prominent intelligence possessed by students based on multiple intelligence theories. The author will give each of the 12 statements for each type of intelligence which are the main characteristics of individuals who have that intelligence.

\subsection{Research Data Analysis}

In this section the results of the performance test data are presented in table form and also present the names of respondents who have multiple intelligences consisting of nine intelligences. Next the researcher conducted a descriptive analysis because of the small number of participants [16].

\section{Result and Discussion}

\subsection{Descriptive Data Analysis}

Performance test results Performance test results data were taken from 69 respondents who were classified based on nine multiple intelligences. Next group the number of students who have more than one intelligence and make a table to see the percentage of dominant intelligence in students. The researcher conducted a description analysis to explain the numbers in the table with literature review.

Tabel 1. Performance Test Results

\begin{tabular}{llcc}
\hline No. & $\begin{array}{c}\text { Types of Intelligence } \\
\text { (Student Dominant Intelligence) }\end{array}$ & n & \% \\
\hline 1. & Linguistic Intelligence & 4 & 5,93 \\
2. & Logical Intelligence & 5 & 7,16 \\
3. & Visual-Spatial Intelligence & 5 & 7,16 \\
4. & Kinesthetic Intelligence & 12 & 17,78 \\
5. & Musical & 19 & 27,41 \\
6. & Intrapersonal Intelligence & 34 & 49,88
\end{tabular}




\begin{tabular}{llcc}
\hline No. & $\begin{array}{c}\text { Types of Intelligence } \\
\text { (Student Dominant Intelligence) }\end{array}$ & n & \% \\
\hline 7. & Interpersonal Intelligence & 24 & 34,57 \\
8. & Naturalistic Intelligence & 30 & 43,96 \\
9. & Spiritual-Existential Intelligence & 44 & 63,42 \\
\hline
\end{tabular}

Based on table 1 about the results of the performance test it can be seen that the number of students who have verbal-linguistic intelligence that stands out as intelligence which is identified as "smart word" is $4(5.93 \%)$. Furthermore, the number of students who have prominent intelligence logic as intelligence which is identified as "smart number" is 5 $(7.16 \%)$.

In table 1 it can be seen that the number of students who have visual-spatial intelligence is prominent, as intelligence identified as "picture smart" is $7(7.15 \%)$. The number of students who have kinesthetic intelligence that stands out, as intelligence identified as "smart body" as many as $12(17.78 \%)$. The number of students who have music-rhythmic intelligence that stands out, as intelligence that is identified as "sound smart" is $19(27.41 \%)$.

The number of students who have prominent intrapersonal intelligence as intelligence identified as "smart with self" as many as $34(49.88 \%)$. The value of $49.88 \%$ indicates that students have intelligence in knowing themselves. Barlow statement, "Personal intelligence allows a person to understand herself by making self-observations, forming a model of herself, making choices based on the self-model and using this information about herself to form plans and goals" [4].

Furthermore, the number of students who have prominent interpersonal intelligence as intelligence identified as "smart people" is $24(34.57 \%)$. The number of students who have prominent naturalistic intelligence as intelligence identified as "nature smart" is $30(43.96 \%)$. The number of students who have prominent intelligence in existential-spiritual intelligence, as intelligence identified as "spiritual smart" is $44(63.42 \%)$.

The highest intelligence possessed by respondents from other types of intelligence is existential-spiritual intelligence as many as 44 (63.42\%). Both intelligence, IQ and EQ, are not enough to pursue and maintain the peak ability and success of human life without involving spiritual intelligence (SQ) [17]. Spiritual intelligence is a dimension of intact intelligence (integral) that encourages people to reach their full potential. "SQ is not an intelligence born of religion, but an innate ability that is free from religion. While IQ and EQ come from thoughts and emotions, SQ is values and meaning"[17].

\subsection{Observation Results and Interviews}

Within the scope of 1st High School Tana Toraja there are many students who do not use prominent intelligence possessed to develop or achieve their own potential. The thing that is the cause is that students do not know or understand clearly the type of prominent intelligence possessed and students are not interested in developing the type of prominent intelligence they have and are more interested in developing the potential of other types of intelligence.

The role of multiple intelligence theory can be seen from two educational agents that are the essence of education itself, namely students (students) and educators (teachers). The role of multiple intelligence for students includes appreciation for the differences and uniqueness of each student, providing an understanding of their own potential, providing guidance in the selection of specializations, providing guidance in selecting extracurricular activities, and providing guidance on finding appropriate learning strategies. For teachers, multiple intelligence theory acts as a guide in choosing a holistic teaching strategy and as a guide in providing evaluations to students. The results achieved and can be seen through the 
development of self-potential based on the type of prominent intelligence that is possessed are the abilities and talents that are increasingly trained, achievements in their respective fields, and good self-understanding such as appropriate learning strategies, good planning about the future and choose the university that is the target of graduation in accordance with the intelligence possessed.

The curriculum, teacher, and students of 1st High School Tana Toraja are very instrumental in developing all types of intelligence contained in multiple intelligences. This can be seen from the self-development activities provided by the school (extracurricular), teaching and learning methods used by the teacher, various activities held by the school through the Student Council, and so on.

At 1st High School Tana Toraja stressed that the learning of Religion and Character Education was well implemented for each student. This is evidenced by the activity of deepening religious subjects (spiritual retreats, basic leadership exercises, etc.), special guidance from religious subject teachers, and motivation from each teacher so students are always active in participating in activities related to religion. In addition, of the ten respondents interviewed by the authors, four of them had existential-spiritual prominent intelligence. The results of the interviews with them showed that the 1st High school Tana Toraja played an active role in developing spiritual existential intelligence that was supported by families specifically parents. One reason for the large number of respondents who have existential-spiritual intelligence is because schools and families strongly support the implementation of religious teachings.

\section{Conclusion}

Based on the performance test each student has a profile or type of intelligence that is different from one another. The results of the performance tests show there are students who stand out in several types of intelligence. The highest intelligence possessed by respondents in research based on performance tests is existential-spiritual intelligence. Such intelligence can develop well in someone if supported by suppressing good religious values. The school specifically in the areas of curriculum, religious education teachers, and the Student Council and the families of the respondents strongly supported the implementation of the planting of good religious values for each student. This is one of the causes of the many respondents who have existential-spiritual intelligence. Intelligence and potential are two things that cannot be separated because intelligence is one part of potential. In addition, intelligence is a guideline or reference for developing self potential because basically the potential is something that is still hidden and needs to be developed through the training process. Comprehensive intelligence provides answers to what must be trained and developed in an individual so that his own potential can be developed properly.

\section{References}

[1] H. Gardner, "The theory of multiple intelligences," Annals of Dyslexia, vol. 37, no. 1, pp. 19-35, Jan. 1987.

[2] H. E. Gardner, Intelligence Reframed: Multiple Intelligences for the 21 st Century. Hachette UK, 2000.

[3] H. Gardner, Multiple Intellegences Memaksimalkan Potensi \& Kecerdasan Individu Dari Masa Kanak-kanak Hingga Dewasa. Jakarta: Daras Books, 2013. 
[4] B. A. Barlow, "What is Self-Potential and How Does It Relate to Personal Intelligence?," University of New Hampshire, Durham, 2016.

[5] W. McKenzie, Multiple intelligences and instructional technology, 2nd ed. Eugene, Or: International Society for Technology in Education, 2005.

[6] B. A. Visser, M. C. Ashton, and P. A. Vernon, "Beyond g: Putting multiple intelligences theory to the test," Intelligence, vol. 34, no. 5, pp. 487-502, Sep. 2006.

[7] H. Soleimani, A. Moinnzadeh, Z. Kassaian, and S. Ketabi, "The Effect of Instruction Based on Multiple Intelligences Theory on the Attitude and Learning of General English," English Language Teaching, vol. 5, no. 9, pp. 45-53, 2012.

[8] R. Abdulkarim and A. Al Jadiry, "The Effect of Cooperative Learning Group Division Based on Multiple Intelligences Theory and Previous Achievement on Scientific Thinking Skills Development of Ninth Grade Students in Oman," European Journal of Social Sciences, vol. 27, no. 4 , pp. 553-569, 2012.

[9] M. A. Suplig, "Pengaruh Kecanduan Game Online Siswa SMA Kelas X Terhadap Kecerdasan Sosial Sekolah Kristen Swasta Di Makassar,” Jurnal Jaffray, vol. 15, no. 2, pp. 177-200, Sep. 2017.

[10] T. Safarai, Interpersonal Intelligence: Metode Pengembangan Kecerdasan Interpersonal Anak. Yogyakarta: Amara Books, 2005.

[11] T. Armstrong, 7 kinds of smart: identifying and developing your multiple intelligences, Rev. and updated with information on 2 new kinds of smart. New York: Plume, 1999.

[12] Y. Taase, "Multiple Intelligences Theory and Iranian Textbooks: An Analysis," Journal of PanPacific Association of Applied Linguistics, vol. 16, no. 1, pp. 73-82, 2012.

[13] C. Cerruti, "Building a functional multiple intelligences theory to advance educational neuroscience," Front. Psychol., vol. 4, pp. 1-4, 2013.

[14] Z. X. Han and W. Wang, "Application of Multimedia and Network English Teaching in Multiple Intelligence Development," AMM, vol. 347-350, pp. 2739-2742, Aug. 2013.

[15] B. A. Pribadi and S. Lestari, "Tes Performa dan Kecerdasan Majemuk," Jurnal Pendidikan, vol. 12, no. 1, pp. 62-73, Aug. 2011.

[16] J. W. Creswell, Research design: qualitative, quantitative, and mixed methods approaches, 4th ed. Thousand Oaks: SAGE Publications, 2014.

[17] R. Griffiths, "The Spiritual Intelligence Paradigm," Spiritual Intelligence. [Online]. Available: https://sqi.co/the-spiritual-intelligence-paradigm/. [Accessed: 25-Mar-2019]. 